\title{
Ultraviolet-B Radiation Alters Soybean Growth and Seed Quality
}

\author{
K. Raja Reddyㅜ, Hrusikesh Patro², Suresh Lokhande³, Nacer Bellaloui ${ }^{4}$, \\ Wei Gao ${ }^{5}$ \\ ${ }^{1}$ Department of Plant and Soil Sciences, Mississippi State University, Mississippi State, USA \\ ${ }^{2}$ Department of Agronomy, Orissa University of Agriculture \& Technology, Bhubaneswar, India \\ ${ }^{3}$ Department of Sociology, lowa State University, Ames, USA \\ ${ }^{4}$ Crop Genetics Research Unit, USDA-ARS, Stoneville, USA \\ ${ }^{5}$ USDA-UV-B Monitoring Network, Natural Resource Ecology Lab, Colorado State University, Fort Collins, USA \\ Email: krreddy@pss.msstate.edu
}

Received 12 December 2015; accepted 25 January 2016; published 28 January 2016

Copyright (C 2016 by authors and Scientific Research Publishing Inc.

This work is licensed under the Creative Commons Attribution International License (CC BY).

http://creativecommons.org/licenses/by/4.0/

c) (i) Open Access

\section{Abstract}

Research on the effects of ultraviolet-B (UV-B) radiation on soybean seed quality is limited. The objective of this study was to quantify UV-B doses, $0,5,10 \& 15 \mathrm{~kJ} \cdot \mathrm{m}^{-2} \cdot \mathrm{d}^{-1}$, on soybean growth and seed quality. The experiment was conducted in the Soil-Plant-Atmosphere-Research (SPAR) facility. Chambers located at the R.R. Foil Plant Science Research Facility of Mississippi State University, Mississippi, USA, were used. Each SPAR chamber consists of a steel soil bin to accommodate the root system, a Plexiglas chamber to accommodate plant canopy and a heating, and cooling system connected to air ducts that pass conditioned air to cause leaf flutter through the plant canopy. The SPAR units, supported by an environmental monitoring and control systems, are networked to provide automatic acquisition and storage of the data, monitored every 10 seconds throughout the day and night. Soybean cultivar Pioneer 93 Y92 (maturity group IV, Roundup Ready) was used in the study. The desired UV-B radiation was supplied by square-wave UV-B supplementation systems under near ambient PAR and delivered to plants for eight hours, each day, from 08:00 to 16:00 h by eight fluorescent UV-313 lamps. The results showed that increased UV-B did not influence many of the growth parameters because the treatments were imposed at mid-fruiting period. Seed quality parameters that are important for seed industry and human and animal nutrition were all affected by UV-B. Protein and palmitic and oleic acids declined linearly, while oil and linoleic and linolenic acid contents increased with increased UV-B. Sucrose, stachyose, and stearic acid contents showed quadratic trends, increased to about 4 - $5 \mathrm{~kJ}$ of UV-B and declined at higher doses. Thus, both current and projected UV-B radiation levels can modify soybean growth and seed quality. The functional algorithms developed in this study could be useful to develop UV-Bspecific sub-models for soybean farm management and in policy decision areas. 


\section{Keywords}

\section{Ultraviolet Radiation, Biomass Parameter, Seed Quality, Soybean Nutrition, Seed Composition}

\section{Introduction}

Soybean is an important source of protein, oil, carbohydrates, isoflavones, and other minerals [1] for humans and animal nutrition [2]. Seed quality is often determined by seed protein, oil, fatty acid, sugars and mineral content. Therefore, maintaining and improving soybean seed quality is a key to overall human and animal nutritional aspects. Projected changes in global climate include increasing atmospheric carbon dioxide concentration, temperatures, and ultraviolet (UV)-B radiation which have significant effects on plant vegetative and reproductive growth. Reductions in ozone column have led to substantial increases in UV-B radiation at the earth's surface with the amount and intensity dependent on atmospheric and geographic factors [3]. During the last few decades, the thinning of the stratospheric ozone has led to the enhanced UV-B radiation on the earth surface [4]. The current UV-B levels of $4-9 \mathrm{~kJ} \cdot \mathrm{m}^{-2} \cdot \mathrm{d}^{-1}$ during June-August 2002 over USA and projected increases of $14 \%$ - $40 \%$ in near future will have profound effects on crop yield and quality. The relative plasticity of soybean growth and development to the current and projected UV-B radiation will play a major role in determining crops future as well the industry needs as quality will be dependent on changes projected in the climate. Numerous studies have shown that enhanced UV-B radiation can affect physiological and biochemical processes of many plant species, including altered plant photosynthesis [5], changes in the carbon partitioning from growth pools to secondary metabolic pathways [6], and thus changes in crop morphology, crop reproductive organ abortion and yield reduction [7].

For the past 10 plus years, the effect of enhanced UV-B radiation on soybean yield has been extensively studied because of the importance of intensity and quality of solar radiation intercepted by the canopy in determining soybean yield and yield components [8]. It was suggested that enhanced UV-B radiation makes the soybean plants to be dwarf by shortening the internodal length [9]. In addition, enhanced UV-B radiation also caused decreased total biomass of soybean by $24 \%$ [10]. Pod number per plant was the most responsible component for yield change under UV-B radiation in the 2-year study. Seed number per pod was less affected by changes in UV-B light treatment, compared with the pod numbers per plant. However, enhanced UV-B radiation has been reported to have no significant effect on effective pod-filling period, but the seed size was negatively impacted and decreased $12 \%$ for three sensitive cultivars [11]. Reduction of seed size was mainly due to the decrease of cotyledon cell number [12]. Studies conducted in China revealed that the soybean crop under exposure to the treatment of weak UV-B radiation during the early stage of pod development greatly decreased seed number as well as seed weight per plant and seed yield [12]. It was reported that seed weight of the 15 out of 20 soybean cultivars decreased when exposed to UV-B radiation [13].

Soybean is mainly produced for oil and soymeal, and the quality of oil and the soymeal depends on the composition of fatty acids and protein, respectively. Soybean seed protein concentration ranges from 341 to 568 $\mathrm{g} \cdot \mathrm{kg}^{-1}$ of total seed weight, with a mean of $421 \mathrm{~g} \cdot \mathrm{kg}^{-1}$. Oil concentration ranges from $83 \mathrm{~g} \cdot \mathrm{kg}^{-1}$ to $279 \mathrm{~g} \cdot \mathrm{kg}^{-1}$ with a mean of $195 \mathrm{~g} \cdot \mathrm{kg}^{-1}$ [14]. Saturated fatty acids in soybean oil range from $100 \mathrm{~g} \cdot \mathrm{kg}^{-1}$ to $120 \mathrm{~g} \cdot \mathrm{kg}^{-1}$ for palmitic acid, and from $22 \mathrm{~g} \cdot \mathrm{kg}^{-1}$ to $72 \mathrm{~g} \cdot \mathrm{kg}^{-1}$ for stearic acid [15]. The mean concentration of unsaturated fatty acids is $240 \mathrm{~g} \cdot \mathrm{kg}^{-1}$ for oleic acid, $540 \mathrm{~g} \cdot \mathrm{kg}^{-1}$ for linoleic acid, and $80 \mathrm{~g} \cdot \mathrm{kg}^{-1}$ for linolenic acid [16]. A negative correlation has been reported between protein and oil concentration and yield in many soybean cultivars [17], and a negative correlation between protein and oil [18]. The average soybean seed contains $9 \%$ to $12 \%$ total soluble carbohydrates, of which $4 \%$ to $5 \%$ are sucrose $\left(\mathrm{C}_{12} \mathrm{H}_{22} \mathrm{O}_{11}\right), 1 \%$ to $2 \%$ are raffinose $\left(\mathrm{C}_{18} \mathrm{H}_{32} \mathrm{O}_{16}\right)$, and $3.5 \%$ to $4.5 \%$ stachyose $\left(\mathrm{C}_{24} \mathrm{H}_{42} \mathrm{O}_{21}\right)$ [11]. Raffinose and stachyose are undesirable components because they have detrimental effects on the nutritive value of the meal and are indigestible by human and animals, often causing flatulence and diarrhea in non-ruminants [18]. Therefore, soybean seed with low raffinose and stachyose is desirable for feeding non-ruminant animals to improve feed energy efficiency, increase mineral uptake, and reduce flatulence [17]. On the other hand, soybean seed with high sucrose concentration is desirable for the seed and food processing industry because it improves taste and flavor in tofu, soy milk and natto [2]. Seed composition constituents have also been reported to be genetically controlled [19]. However, seed composition has also 
shown to be affected by environment [20], genotype, maturity, diseases [21], temperature [20], drought [22], nutrients in soil and seed [23].

Understanding soybean responses to the increasing intensities of UV-B radiation is much needed to develop suitable management and cultural practices for the present and future climates. Some studies have been carried out either under greenhouse or under unrealistic solar radiation environments and results may not be portable to field situations. Studies have been conducted on other crops such as wheat [24] and corn [25]. The effect of enhanced UV-B radiation on soybean physiology and yield has been studied extensively. However, information on the effects of enhanced UV-B radiation on seed quality characteristics of soybean is limited and little information is available concerning the UV-B radiation effects on the relationship among growth, seed yield and seed quality traits [26]. The objective of this study was to investigate the effect of UV-B radiation on soybean growth and seed quality as soybean seed nutrition is important for human and animal nutrition.

\section{Materials and Methods}

\subsection{Facilities and Growth Conditions}

The Soil-Plant-Atmosphere-Research (SPAR) chambers located at the R.R. Foil Plant Science Research facility of Mississippi State University ( $\left.33^{\circ} 28 \mathrm{~N}, 88^{\circ} 47 \mathrm{~W}\right)$, Mississippi, USA were used for this study. Briefly, each SPAR chamber consists of a steel soil bin ( $1 \mathrm{~m}$ deep by $2 \mathrm{~m}$ long by $0.5 \mathrm{~m}$ wide) to accommodate the root system, a Plexiglas chamber ( $2.5 \mathrm{~m}$ tall by $2 \mathrm{~m}$ long by $1.5 \mathrm{~m}$ wide) to accommodate plant canopy and a heating and cooling system connected to air ducts that pass conditioned air to cause leaf flutter through the plant canopy. The SPAR units supported by an environmental monitoring and control systems are networked to provide automatic acquisition and storage of the data, monitored every $10 \mathrm{~s}$ throughout the day and night. Many details on the operation and control of SPAR chambers were described by others [27].

Soybean cultivar Pioneer 93 Y92 (maturity group IV, Roundup Ready) seeds were planted on 5 July 2011 in pots $(22 \mathrm{~cm}$ tall and $22 \mathrm{~cm}$ diameter) filled with fine sand and soil mixed in the ratio of 75:25. Seventy pots having planted with 3 seeds per pot were maintained in an outdoor environment. In each pot one healthy plant per pot was maintained a week after emergence. Twelve pots, 1 plant pot $^{-1}$ and 3 plants row ${ }^{-1}$, were arranged in 6 rows in each of the 4 SPAR chambers on 27 August 2011. Plants were watered three times a day with halfstrength Hoagland's nutrient solution [28], delivered at 0800,1200 , and $1600 \mathrm{~h}$, to ensure favorable nutrient and water conditions for plant growth through an automated and computer-controlled drip system. Variable-density black shade cloth around the edges of plants was adjusted regularly to match plant height in order to simulate natural shading caused by presence of other plants. The treatments included 4 biologically effective UV-B radiation intensities of $0,5,10$, and $15 \mathrm{~kJ} \cdot \mathrm{m}^{-2} \cdot \mathrm{d}^{-1}$. The treatments were imposed on plants when they are at the middle of the pod-filling stage, 65 days after sowing.

The desired UV-B radiation was supplied by square-wave UV-B supplementation systems under near ambient PAR. The UV-B radiation was delivered to plants for eight hours, each day, from 08:00 to 16:00 h by eight fluorescent UV-313 lamps (Q-Panel Company, Cleveland, Ohio, USA) powered by $40 \mathrm{~W}$ variable dimming ballasts. The lamps were wrapped with pre-solarized $0.07 \mathrm{~mm}$ cellulose diacetate film to filter UV-C $(<280 \mathrm{~nm})$ radiation. The cellulose diacetate film was changed at 3 - $4 \mathrm{~d}$ intervals. The UV-B energy delivered at the top of the plant canopy was checked daily at 09:00 h with a UVX digital radiometer (UVP Inc., San Gabriel, CA, USA) calibrated against an Optronic Laboratory (Orlando, FL, USA) Model 754 Spectroradiometer, which was used initially to quantify lamp output. The lamp output was adjusted, as needed, to maintain the respective UV-B radiation levels. A distance of $0.5 \mathrm{~m}$ from lamps to the top of plants was always maintained throughout the experiment. The actual biologically effective UV-B radiation was measured during the crop growth period at six different locations in each SPAR unit corresponding to the pots arranged in rows. The weighted total biologically effective UV-B radiation at the top of the plant canopy during the treatment period is presented in Figure 1. The set UV-B conditions, average temperature, and measured chamber $\mathrm{CO}_{2}$ from a typical day during the experimental period for each treatment is mentioned in Table 1.

Final harvesting was carried out on 13 October 2011 (100 DAS or 47 days after UV-B treatment). Plants were cut above ground and separated into roots, leaves, pods, and stems. Pods were kept outside under normal drying conditions while other plant parts were dried in oven at $75^{\circ} \mathrm{C}$ until it weighed constant during a period of $72 \mathrm{~h}$. The biomass parameters such as dry weight of leaf, stem, root and total per plant, number of pods and seeds per plant, number of seeds per pod as well as seed weight per seed were measured. 


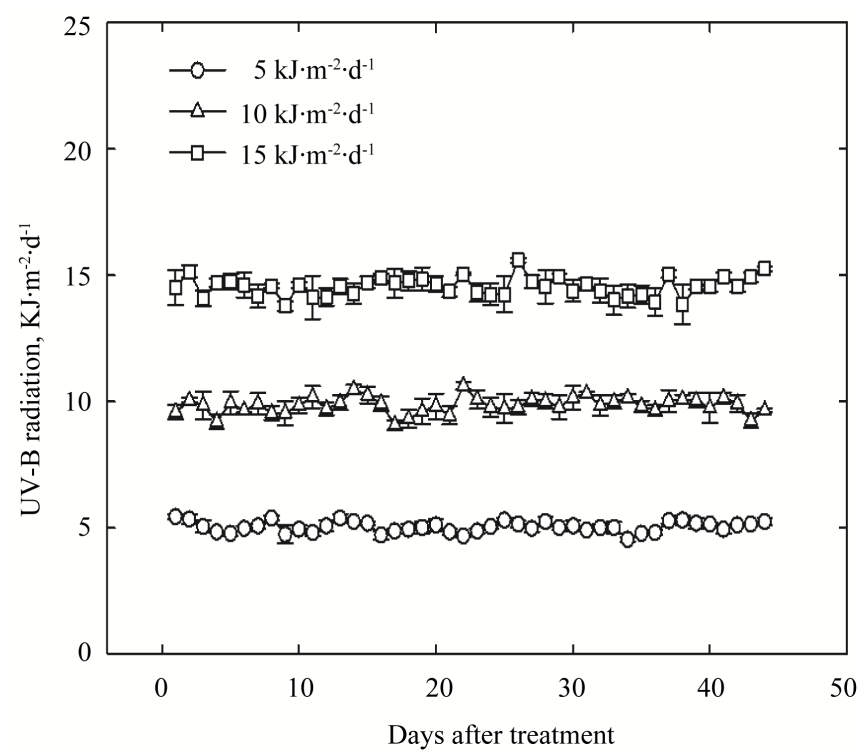

Figure 1. Daily ultraviolet-B (UV-B) radiation doses for three UV-B treatments measured at the top of the canopies, and lamps placed at $0.5 \mathrm{~m}$ above the canopy. Each data point is mean of three measurements measured at 4 different locations in each treatment and standard errors are shown if the values are larger than the symbols. The UV-B doses were measured daily at 10:00 $\mathrm{h}$ and adjusted to the target levels of 5,10 , or $15 \mathrm{~kJ} \cdot \mathrm{m}^{-2} \cdot \mathrm{d}^{-1}$.

Table 1. The Set Ultraviolet (UV)-B conditions, average temperature, and measured chamber $\mathrm{CO}_{2}$ from a typical day during the experimental period for each treatment.

\begin{tabular}{ccc}
\hline Treatments & \multicolumn{2}{c}{ Measured variables } \\
\hline $\mathrm{UV}-\mathrm{B}\left(\mathrm{kJ} \cdot \mathrm{m}^{-2} \cdot \mathrm{d}^{-1}\right)$ & Mean temperature $\left({ }^{\circ} \mathrm{C}\right)$ & $\mathrm{Chamber} \mathrm{CO}_{2}\left(\mu \mathrm{mol}^{\circ} \mathrm{mol}^{-1}\right)$ \\
\hline 0 & $29.6 \pm 0.04$ & $409 \pm 2.2$ \\
5 & $29.7 \pm 0.03$ & $407 \pm 3.1$ \\
10 & $29.3 \pm 0.05$ & $406 \pm 2.3$ \\
15 & $29.6 \pm 0.03$ & $404 \pm 2.7$ \\
\hline
\end{tabular}

Each value represents the mean $\pm \mathrm{SE}$ (standard error of the mean) for one typical day for $\left[\mathrm{CO}_{2}\right]$, and 27 August to 13 October 2011 for temperature.

\subsection{Seed Analysis for Protein, Oil, Fatty Acids, Sucrose, Raffinose, and Stachyose}

Seed pooled from each row of plants were analyzed for protein, oil, fatty acids, sucrose, raffinose and stachyose. About $25 \mathrm{~g}$ of seed from each pot was ground using a Laboratory Mill 3600 (Perten, Springfield, IL). Analyses were conducted by near infrared reflectance [29] using a diode array feed analyzer AD 7200 (Perten). Calibrations were developed by the University of Minnesota, using Perten's Thermo Galactic Grams PLS IQ software. To improve accuracy, the calibration curve was updated as needed for oil, fatty acids, protein, sucrose, raffinose, and stachyose. Analyses of protein, oil, and sugars were performed based on a seed diameter basis [29] [30]. Fatty acids are analyzed on oil basis.

\subsection{Statistical Analysis}

To test the significance of UV-B radiation on growth and biomass components of soybean, analysis of variance was performed by using general linear model PROC GLM (SAS Institute Inc., Cary, NC, USA). Fisher protected LSD tests at $\mathrm{P}=0.05$ was used to determine significance of treatment effects. Regression analysis was performed between seed quality parameters and UV-B radiation using SAS (Sas Institute, Inc.) and SigmaPlot 
11.0 (Systat Software Inc., San Jose, CA, USA) and best fit regression models were selected based $\mathrm{R}^{2}$ values. The graphical analysis was carried out using SigmaPlot.

\section{Results and Discussion}

\subsection{Treatments and Growth Parameters}

The ultraviolet-B radiation treatments were very close to the set points (Figure 1). The treatments represent the UV-B doses that are currently experienced for soybean and all other crops cultivated between $40^{\circ} \mathrm{N}$ and $40^{\circ} \mathrm{S}$ latitudes, currently at 2 to $10 \mathrm{~kJ} \cdot \mathrm{m}^{-2} \cdot \mathrm{d}^{-1}$ depending on location and season [31] [32] and within the limits of projected UV-B in the $21^{\text {st }}$ century [33]. Biomass parameters under UV-B radiation and natural light conditions obtained were summarized in Table 2. The effect of increasing levels of UV-B radiation at 5,10 or $15 \mathrm{~kJ} \cdot \mathrm{m}^{-2} \cdot \mathrm{d}^{-1}$ in respect of root and total dry weight per plant as well as number of seeds per pod over natural light (control, 0 UV-B radiation) was found non-significant. However, the total dry weight per plant decreased at all the UV-B radiation levels compared with the control, but the reduction was more at $10 \mathrm{~kJ} \cdot \mathrm{m}^{-2} \cdot \mathrm{d}^{-1}$ compared to either 5 or $15 \mathrm{~kJ} \cdot \mathrm{m}^{-2} \cdot \mathrm{d}^{-1}$. This is in agreement with the study of Feng et al. [10] where enhanced UV-B radiation decreased total biomass soybean by $24 \%$. Leaf dry weight had no distinct pattern with increasing levels of UV-B radiation. Stem dry weight, pod dry weight, number of pods, seeds per plant, and individual seed weight showed lower values at higher doses of UV-B compared to the control. However, the reduction in single seed weight was consistent with concomitant increase in UV-B radiation doses up to $15 \mathrm{~kJ} \cdot \mathrm{m}^{-2} \cdot \mathrm{d}^{-1}\left(0.20 \mathrm{~g} \cdot \mathrm{seed}^{-1}\right)$, which is significantly lower in comparison to control $\left(0.22 \mathrm{~g} \cdot \mathrm{seed}^{-1}\right)$.

Seed weight was negatively impacted by UV-B radiation. Chen et al. [13] reported similar findings in that seed weight of the 15 soybean cultivars out of 20 significantly decreased. Seed size was a function of the rate of seed growth and the duration of dry weight accumulation in the seed fraction and thereby the dry weight. Seed growth rate was shown to be a function of the cotyledon cell number and the supply of assimilate to the developing cotyledons [34]. Reduction of seed size was mainly due to the decrease of cotyledon cell number [11].

Stem and pod dry weight per plant were reduced by UV-B radiation up to $10 \mathrm{~kJ} \cdot \mathrm{m}^{-2} \cdot \mathrm{d}^{-1}$, while it enhanced at $15 \mathrm{~kJ} \cdot \mathrm{m}^{-2} \cdot \mathrm{d}^{-1}$, but the enhancement remained lower than control. The significant reduction in stem and pod dry weight at $10 \mathrm{~kJ} \cdot \mathrm{m}^{-2} \cdot \mathrm{d}^{-1}$ were of the order of 30 and $12 \%$ over control, respectively, while reductions were close and comparable with $5 \mathrm{~kJ} \cdot \mathrm{m}^{-2} \cdot \mathrm{d}^{-1}$. Decreased stem dry weight might be due to reduction in main stem and branch elongation rates upon enhanced UV-B radiation resulting more compact and shorter plants [35]. It was suggested that enhanced UV-B radiation makes the soybean plant dwarf by shortening the internode length [9]. It was reported, working on pea plants, that low doses of ultraviolet-B or ultraviolet-C radiation had affected phytohormones, including indoleacetic acid (IAA) and abscisic acid (ABA) [36]. Mark and Tevini [37] speculated that the mechanism for reduced stem elongation by UV-B might be due to changes in the phytohormone levels, especially IAA which plays a role in stem elongation. It was also confirmed that UV-B radiation decreased plant height of two soybean cultivars $10 \%$ and $15 \%$, and decreased dry weight of individual stem by

Table 2. Biomass parameters of soybean as influenced by enhanced doses of UV-B radiation ${ }^{\mathrm{m}}$.

\begin{tabular}{|c|c|c|c|c|c|}
\hline \multirow{2}{*}{ Biomass parameters } & \multicolumn{4}{|c|}{ UV-B radiation, $\mathrm{kJ} \cdot \mathrm{m}^{-2} \cdot \mathrm{d}^{-1}$} & \multirow{2}{*}{ F test } \\
\hline & 0 & 5 & 10 & 15 & \\
\hline Leaf dry weight, g & $20.6 b c$ & 24.2ab & $20.4 c$ & $24.4 a$ & 3.67 \\
\hline Stem dry weight, g & $30.3 a$ & $29.5 a$ & $23.2 b$ & $30.1 \mathrm{a}$ & 4.27 \\
\hline Root dry weight, g & $18.4 \mathrm{a}$ & $16.8 \mathrm{a}$ & $17.7 \mathrm{a}$ & $17.7 \mathrm{a}$ & ns \\
\hline Pod dry weight, g & $75.8 \mathrm{a}$ & $68.1 b$ & $67.5 b$ & 69.3ab & 7.51 \\
\hline Total dry weight, g & 145.0a & 138.5a & $128.8 \mathrm{a}$ & $141.5 a$ & ns \\
\hline Pods, no. plant ${ }^{-1}$ & 109.9a & 101.6b & 105.7ab & 107.8ab & 6.57 \\
\hline Seeds, no. plant ${ }^{-1}$ & 259.3a & $237.7 b$ & 248.4ab & 258.8a & 16.19 \\
\hline Seeds, no. pod $^{-1}$ & $2.36 a$ & $2.34 a$ & $2.35 a$ & $2.41 \mathrm{a}$ & ns \\
\hline Seed weight, g·seed ${ }^{-1}$ & $0.22 \mathrm{a}$ & $0.21 \mathrm{ab}$ & $0.21 b$ & $0.20 \mathrm{~b}$ & 0.013 \\
\hline
\end{tabular}

${ }^{\mathrm{m}}$ Values are means of four replicates; $\mathrm{ns}=$ Not significant at $\mathrm{p}=5 \%$; means within columns followed by the same letter are not significantly different at the $5 \%$ level. 
$44 \%$ and $28 \%$ [38].

Pod and seed number per plant were significantly decreased by UV-B radiation up to $5 \mathrm{~kJ} \cdot \mathrm{m}^{-2} \cdot \mathrm{d}^{-1}$, exhibiting 8 and $9 \%$ reduction compared with control, respectively, where as it increased at 10 and $15 \mathrm{~kJ} \cdot \mathrm{m}^{-2} \cdot \mathrm{d}^{-1}$, and the increases were maintained lower than control. UV-B radiation decreased average pod number per plant of three soybean cultivars by $34 \%$. This suggests that UV-B radiation imposed during early flowering stage would change assimilates availability to the developing reproductive structures, influence flowering, and flower and pod abscission number with a resultant change in final pod number at harvest. Pod number per plant was the yield component most influenced by change in cultural and environmental conditions [39]. In our study, UV-B radiation had no significant effect on seed number per pod (Table 1). Herbert and Litchfield [40] and Board et $a l$. [41] reported that seed number per pod is a minor component determining the yield of soybean. However, the small tendency of decreased seed number per pod under UV-B radiation indicated that seed number per pod is strongly determined by the internal genetic mechanism, and is less influenced by environment condition.

The attenuation of the stratospheric ozone has led to the enhanced UV-B radiation on the surface of land in recent decades [42]. The present study confirmed previous reports [9] [43] that UV-B radiation in the canopy changed soybean agronomic traits and decreased yield per plant. Furthermore solar UV-B radiation exclusion studies indicated that ambient levels of solar UV-B radiation reduce biomass accumulation and grain yield of soybean [44]. Few studies indicated a breakdown of IAA on exposure to UV-B radiation [45]. Crop biomass production in response to UV-B radiation was highly UV-B dosage dependent. The effects of enhanced UV-B radiation on plant growth and dry matter accumulation in growth chamber or greenhouse were usually much higher than those in field conditions [46]. In field conditions UV-B caused decreases in total above ground production of soybean when PAR and UV-A were reduced to less than half their flux in sunlight [47]. The UV-B radiation appears to have a strong ameliorating effect when PAR is not high.

\subsection{Seed Quality Parameters}

\subsubsection{Seed Protein}

Although crop yield and seed quality are important products of soybean crop, few studies addressed UV-B effects on seed quality parameters that are important to human and animal nutrition. Soybean seed protein reported in this study under various UV-B treatments, 407 to $440 \mathrm{~g} \cdot \mathrm{kg}^{-1}$, is within the range, $340-570 \mathrm{~g} \cdot \mathrm{kg}^{-1}$, reported in other studies (Wilson 2004). Seed protein content, however, declined linearly with increase in UV-B radiation, $2.21 \mathrm{~g} \mathrm{~kg}^{-1} \mathrm{UV}^{-B^{-1}}$ (Figure 2). Since seed protein content is governed by nitrogen availability, UV-B might

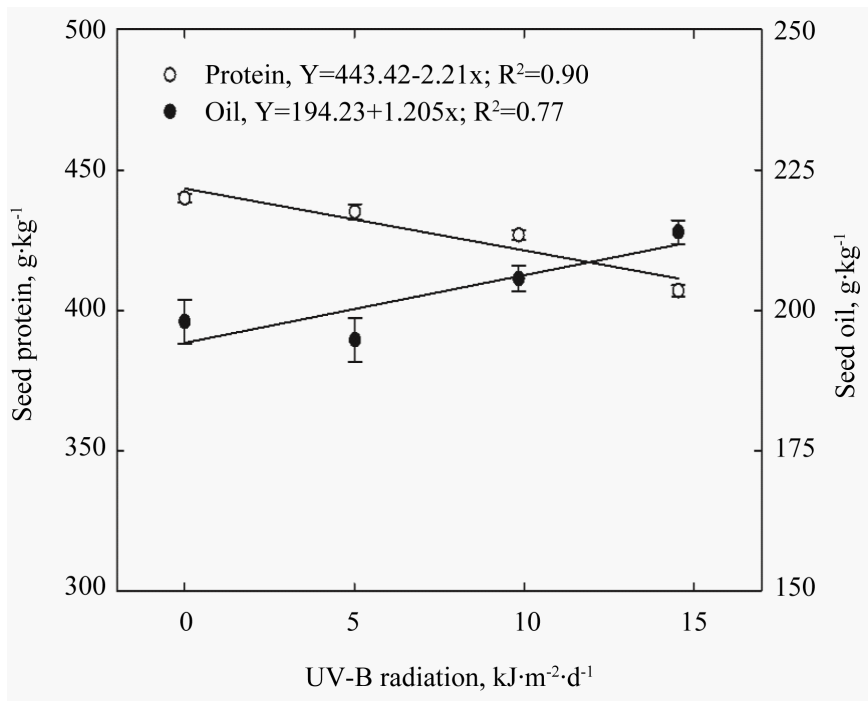

Figure 2. Ultraviolet (UV)-B radiation effects on soybean seed protein and oil content for plants harvested at 100 days after sowing. The UV-B treatments were imposed at early-pod-filling stage, 65 days after sowing. Each data point is mean of four replications and standard errors are shown if the values are larger than the symbols. 
have affected both uptake and translocation of nutrients as reported in other studies under UV-B treatments in soybean and other plants under UV-B radiation [25] [48] [49].

\subsubsection{Seed 0il}

Soybean seed oil is an important product with many industrial application. The seed oil content of found in this study ranges from 198 to $238 \mathrm{~g} \cdot \mathrm{kg}^{-1}$, are with the ranges reported in the literature of about 83 to $279 \mathrm{~g} \cdot \mathrm{kg}^{-1}$, depending on cultivar and growing season environment [14]. Unlike, seed protein content, soybean seed oil increased linearly with $1.205 \mathrm{~g} \cdot \mathrm{kg}^{-1} \mathrm{UV}-\mathrm{B}^{-1}$ (Figure 2). Alan et al. [50] reported similar declines in seed protein and oil content of two soybean cultivars with increased UV-B radiation. The seed protein content of the soybean cultivar Essex was decreased up to $5 \%$ while the seed oil content had no significant changes due to enhanced UV-B radiation. Reductions in seed protein content were observed in cultivar Williams in two of the years while it increased in two other years. Seed oils were also variously affected with reductions of $10 \%$ in one year and an increase of $8 \%$ in another year. However, no changes grain protein in maize and gluten concentration in wheat have been reported in non-leguminous plants [51].

The inverse negative relationship between soybean seed protein and oil $\left(\mathrm{y}=752-1.6 \mathrm{x} ; \mathrm{R}^{2}=0.88\right.$, where $\mathrm{y}=$ $\mathrm{g} \cdot \mathrm{kg}^{-1}$ protein and $\mathrm{x}=\mathrm{g} \cdot \mathrm{kg}^{-1}$ oil) observed in our study when used all treatments and inverse relations with protein and yield [52] observed in many studies poses many challenges to breeders and farm managers to increase protein without reducing grain yield. Breeders have to consider UV-B into their grand scheme of things while increasing the soybean seed yield to meet the future human and animal nutrition with altered climate change.

\subsubsection{Seed Fatty Acids}

Soybean oils contain about 16\% saturated, 23\% monosaturated and 58\% polysaturated fatty acids and these fatty acid composition play important roles in oil stability and human and animal nutrition [51]. The saturated fatty acids such as palmitic and stearic acid contents in seed oil showed linear and quadratic trends with increasing UV-B levels (Figure 3). The decline in pamitic acid content was $0.9459 \mathrm{~g} \cdot \mathrm{kg}^{-1} \mathrm{UV}-\mathrm{B}^{-1}$. On the other hand, maximum stearic acid content of $40.5 \mathrm{~g} \cdot \mathrm{kg}^{-1}$ was observed at $4.94 \mathrm{~kJ}$ of UV-B and declined at higher and 0 UV-B levels. Plants grown at the highest UV-B had 28\% less stearic acid content than the maximum levels observed at $4.94 \mathrm{~kJ}$ of UV-B. The most common monosaturated fatty acid in plants, oleic acid, declined linearly with increase in UV-B doses, $6.734 \mathrm{~g} \cdot \mathrm{kg}^{-1} \mathrm{UV}-\mathrm{B}^{-1}$ (Figure 3). The polysaturated fatty acids, linoleic and linolenic acid contents, on the other hand, increased with increase in UV-B doses (Figure 3). The increase was steeper for linolenic acid (69.45 g. kg $\left.{ }^{-1} \mathrm{UB}-\mathrm{B}^{-1}\right)$ compared with increase in linoleic acid $\left(0.1903 \mathrm{~g} \cdot \mathrm{kg}^{-1} \mathrm{UV}-\mathrm{B}^{-1}\right)$. High oleic acid and low linoleic and linolenic acids are desirable because they contribute to oil stability and human and animal nutrition [51].

\subsubsection{Seed Sugars}

Growing season environment such as temperature [20], genotypes, maturity and diseases [21], drought [22], and nutrients [23] affects soybean seed composition. Sucrose and stachyose contents showed quadratic trends with increasing UV-B doses, maximum sucrose of $38 \mathrm{mg} \cdot \mathrm{g}^{-1}$ was found at $4.27 \mathrm{~kJ}$ of UV-B (Figure 4). Raffinose content, on the other hand, declined linearly with increase in UV-B doses, $0.013 \mathrm{mg} \cdot \mathrm{g}^{-1} \mathrm{UV}-\mathrm{B}^{-1}$. Experiments conducted by Gao et al. [25] also reported that maize seed sugar and starch contents decreased with enhanced UV-B irradiance similar to our results in soybean. Similarly, higher UV-B treatments showed decreased wheat grain sugar content [24]. Raffinose and stachyose are undesirable components because they have detrimental effects on the nutritive value of the meal and are indigestible by human and animals, often causing flatulence and diarrhea in non-ruminants [18]. Therefore, soybean seed with low raffinose and stachyose is desirable for feeding non ruminant animals to improve feed energy efficiency, increase mineral uptake, and reduce flatulence [53]. On the other hand, soybean seed with high sucrose is desirable because it improves taste and flavor in tofu, soy milk and natto [2].

\section{Conclusion}

This study reports the biomass and seed quality responses of soybean crop exposed to enhanced UV-B irradiance under sunlit controlled plant growth chamber conditions. Enhanced UV-B irradiance caused significant reductions in certain plant growth parameters, but the influence was not consistent as the treatments were 


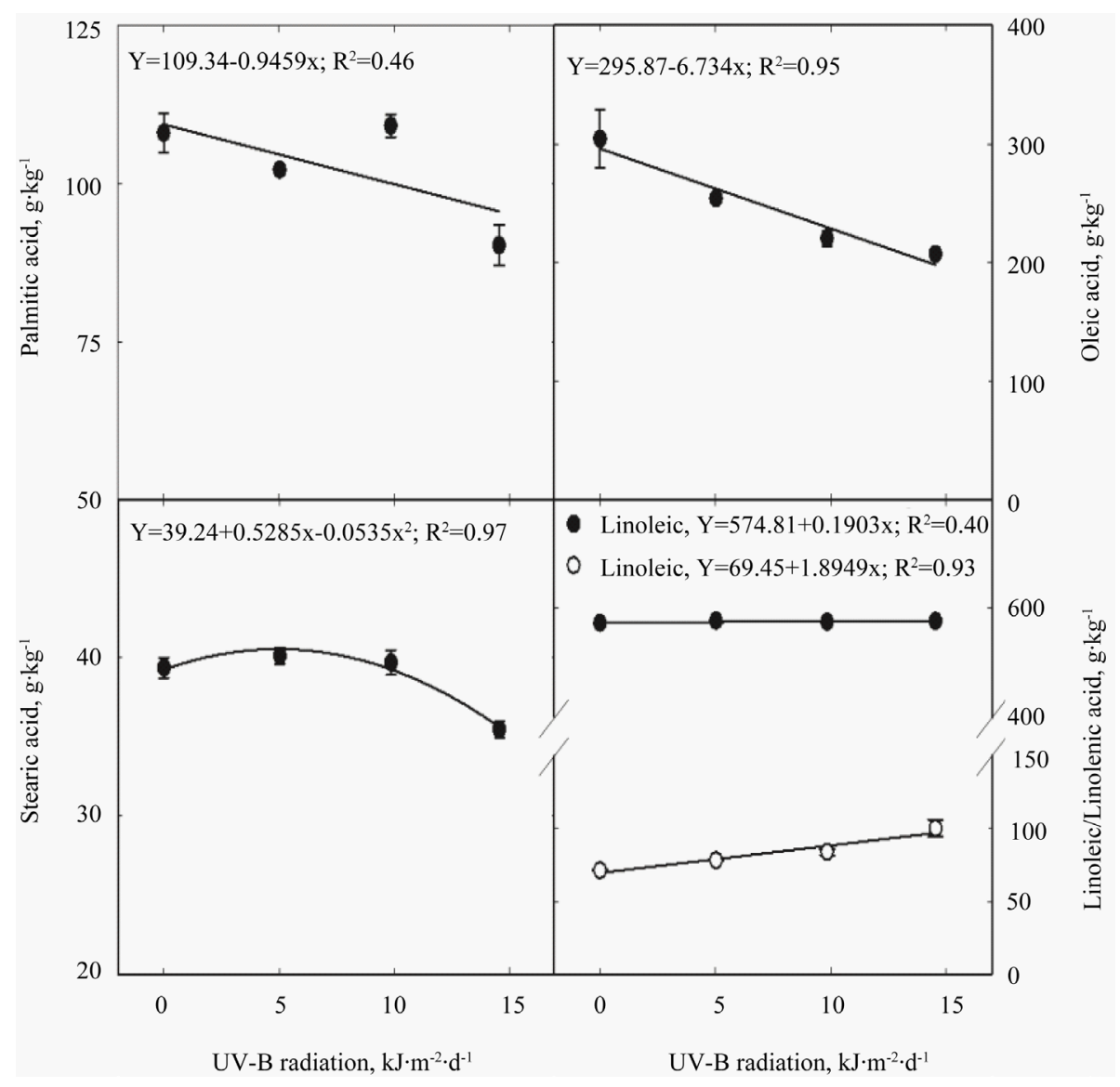

Figure 3. Ultraviolet (UV)-B radiation effects on soybean seed fatty acid content for plants harvested at 100 days after sowing. The UV-B treatments were imposed at early-pod-filling stage, 65 days after sowing. Each data point is mean of four replications and standard errors are shown if the values are larger than the symbols.

imposed during mid-fruiting period. The protein, oil, fatty acid and sugar contents in soybean plants are critical to soybean seed industry and human and animal nutrition. Increased UV-B radiation altered soybean seed quality. Seed protein declined linearly while oil content increased with increase in UV-B radiation. Changes in these two important seed quality parameters have implications for seed industry and animal and human nutrition. The negative correlation between seed protein and oil content and their opposite responses to increasing UV-B doses poses challenges for breeders to develop soybean cultivars better suited for human and animal nutrition in a changing climate. The desirable fatty acids such as oleic acid declined while the linoleic and linolenic acids increased with increase in UV-B radiation. Palmitic and stearic acids showed linear and quadratic trends with increasing UV-B doses. While lower levels of desirable sugars such as raffinose declined linearly while stachyose increased up to 4 - $5 \mathrm{~kJ}$ and declined at higher UV-B treatments will have positive effects on improved feed energy efficiency in non-ruminant animals. The declined sucrose content at higher UV-B doses compared to the levels typically seen in soybean growing areas $(\sim 5 \mathrm{~kJ})$, will have serious implications for human consumption. The functional relationships between UV-B radiation and soybean seed quality parameters will be useful to develop seed quality-specific sub-models under optimal temperature and nutrient conditions. Models equipped with seed quality would be useful not only for production optimization of natural resources such as water and nutrients, but also useful in assisting planting dates in the current environment and in policy decisions for the hypothesized changes in global environmental change on soybean production in the future.

\section{Acknowledgements}

We thank Mr. David Brand for their technical assistance. This article is a contribution from the Department of 


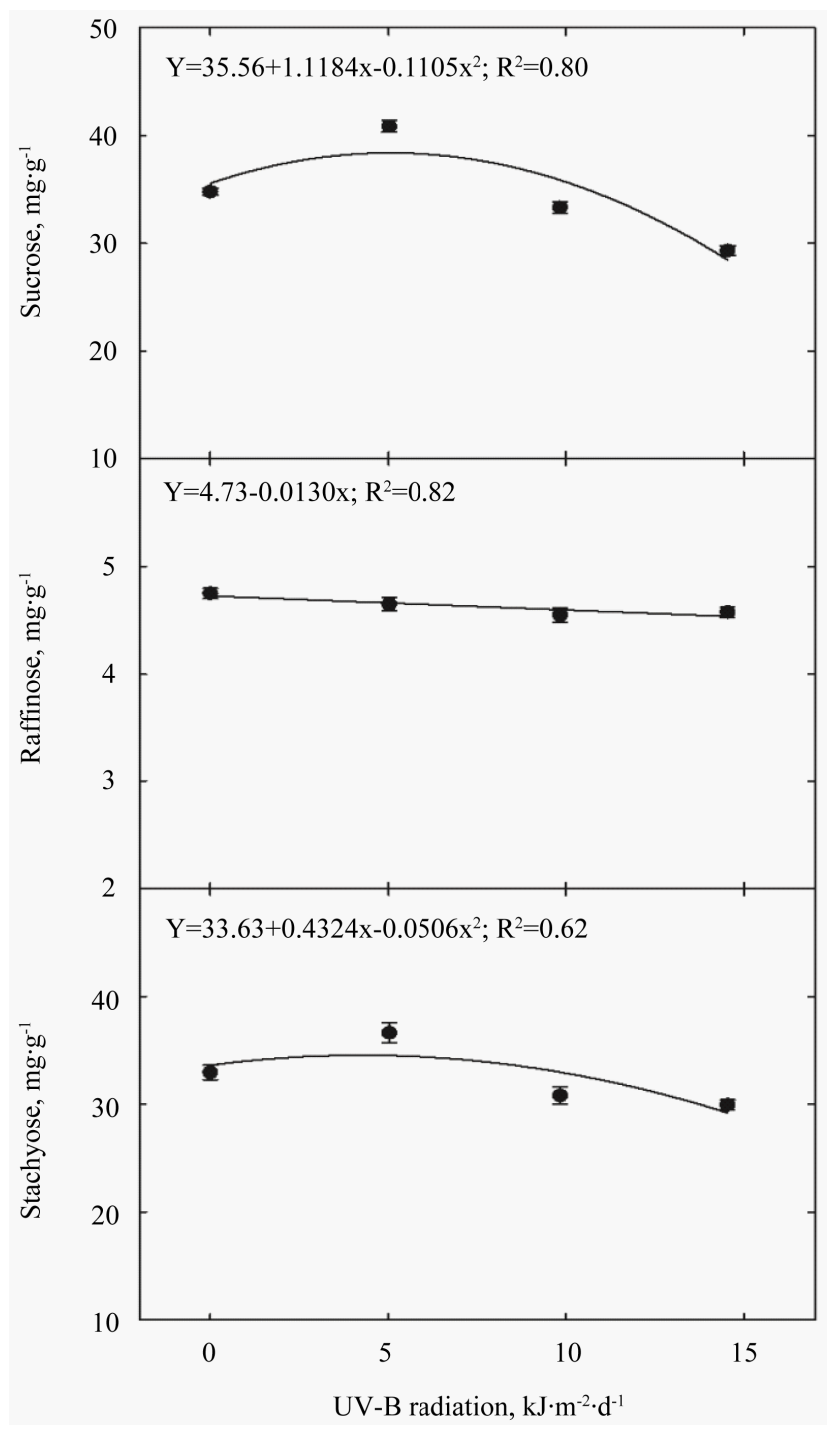

Figure 4. Ultraviolet (UV)-B radiation effects on soybean seed sugar contents for plants harvested at 100 days after sowing. The UV-B treatments were imposed at early-pod-filling stage, 65 days after sowing. Each data point is mean of four replications and standard errors are shown if the values are larger than the symbols.

Plant and Soil Sciences, Mississippi State University, Mississippi Agricultural and Forestry Experiment Station, paper no. J-12658. Mention of trade names or commercial products in this publication is solely for the purpose of providing specific information and does not imply recommendation or endorsement by the Unites States Department of Agriculture (USDA). USDA is an equal opportunity provider and employer. This work was in part funded by the USDA-NIFA 2013-34263-20931, sub-award to Mississippi State University, G-7799-2. Funding for this research was also partially provided by USDA, Agricultural Research Service projects 6066-21220-01200D and 6066-21000-051-00D.

\section{References}

[1] Grieshop, C.M. and Fahey, G.C. (2001) Comparison of Quality Characteristics of Soybeans from Brazil, China, and the United States. Journal of Agriculture and Food Chemistry, 49, 2669-2673. http://dx.doi.org/10.1021/jf0014009

[2] Hou, A., Chen, P., Alloatti, J., Li, D., Mozzoni, L., Zhang, B. and Shi, A. (2009) Genetic Variability of Seed Sugar Content in Worldwide Soybean Germplasm Collections. Crop Science, 49, 903-912. 
http://dx.doi.org/10.2135/cropsci2008.05.0256

[3] Madronich, S., McKenzie, R.L., Bjorn, O. and Caldwell, M.M. (1998) Changes in Biologically Active Ultraviolet Radiation Reaching the Earth Surface. Journal of Photochemistry and Photobiology B: Biology, 46, 5-19. http://dx.doi.org/10.1016/S1011-1344(98)00182-1

[4] McKenzie, R.L., Conner, B. and Bodeker, G. (1999) Increased Summer Time UV Radiation in Four Aquatic Macrophytes. Chemosphere, 74, 642-647.

[5] Reddy, K.R., Kakani, V.G., Zhao, D., Koti, S. and Gao, W. (2004) Interactive Effects of Ultraviolet-B Radiation and Temperature on Cotton Physiology, Growth, Development and Hyperspectral Reflectance. Photochemistry and Photobiology, 79, 416-427. http://dx.doi.org/10.1562/2003-11-19-RA.1

[6] Bassman, J.H. (2004) Ecosystem Consequences of Enhanced Solar Ultraviolet Radiation: Secondary Plant Metabolites as Mediators of Multiple Trophic Interactions in Terrestrial Communities. Photochemistry and Photobiology, 79, $382-$ 398. http://dx.doi.org/10.1562/SI-03-24.1

[7] Mohammed, A.R. and Tarpley, L. (2010) Differential Response of Southern US Rice (Oryzasativa L.) Cultivars to Ultraviolet-B Radiation. Journal of Agronomy and Crop Science, 196, 286-295.

[8] Board, J.E. and Harville, B.G. (1996) Growth Dynamics during the Vegetative Period Affects Yield of Narrow-Row, Late-Planted Soybean. Agronomy Journal, 88, 567-572. http://dx.doi.org/10.2134/agronj1996.00021962008800040012x

[9] Barnes, P.W., Flint, S.D. and Caldwell, M.M. (1990) Morphological Response of Crop and Weed Species of Different Growth Forms to UV-B Radiation. American Journal of Botany, 77, 1354-1360. http://dx.doi.org/10.2307/2444596

[10] Feng, H.Y., Chen, T., Xu, S.J., An, L.Z., Qiang, W.Y., Zhang, M.X. and Wang, X.L. (2001) Effect of Enhanced UV-B Radiation on Growth, Yield and Stable Carbon Isotope Composition in Glycine max Cultivars. Acta Botanica Sinca, 43, 709-713.

[11] Kim, E.H., Seguin, P., Lee, J.E., Yoon, C.G., Song, H.K., Ahn, J.K. and Chung, I.M. (2011) Elevated Ultraviolet-B Radiation Reduces Concentrations of Isoflavones and Phenolic Compounds in Soybean Seeds. Journal of Agro Crop Science, 197, 75-80. http://dx.doi.org/10.1111/j.1439-037X.2010.00444.x

[12] Liu, X.B., Li, Y.S. and Herbert, S.J. (2004) Effects of Enhanced UV-B Radiation on Seed Growth Characteristics and Yield Components in Soybean. Field Crops Research, 154, 158-163. http://dx.doi.org/10.1016/j.fcr.2013.08.006

[13] Chen, J.J., Zu, Y.Q., Chen, H.Y. and Li, Y. (2004) Influence of Enhanced UV-B Radiation on Growth and Biomass Allocation of Twenty Soybean Cultivars. Journal of Agriculture and Environmental Sciences, 23, 29-33.

[14] Wilson, R.F. (2004) Seed Composition. In: Boerma, H. and Specht, J.E., Eds., Soybeans: Improvement, Production, and Uses, 3rd Edition, ASA, CSSA, and SSSA, Madison, 621-668.

[15] Cherry, J.H., Bishop, L., Hasegawa, P.M. and Leffler, H.R. (1985) Differences in the Fatty Acid Composition of Soybean Seed Produced in Northern and Southern Areas of the U.S.A. Phytochemistry, 24, 237-241. http://dx.doi.org/10.1016/S0031-9422(00)83527-X

[16] Schnebly, S.R. and Fehr, W.R. (1993) Effect of Years and Planting Dates on Fatty Acid Composition of Soybean Genotypes. Crop Science, 33, 716-719. http://dx.doi.org/10.2135/cropsci1993.0011183X003300040016x

[17] Burton, J.W. (1984) Breeding Soybean for Improved Protein Quantity and Quality. In: Shibles, R., Ed., Proceedings of World Soybean Research Conference, III, Ames, Westview Press, Boulder, 361-367.

[18] Liu, K. (1997) Soybeans Chemistry, Technology, and Utilization. Chapman \& Hall, New York.

[19] Hartwig, E.E. and Kilen, T.C. (1991) Yield and Composition of Soybean Seed from Parents with Different Protein, Similar Yield. Crop Science, 31, 290-292. http://dx.doi.org/10.2135/cropsci1991.0011183X003100020011x

[20] Dardanelli, J.L., Balzarini, Martinez, J., Cuniberti, M., Resnik, S., Ramunda, S.F., Herrero, R. and Baigorri, H. (2006) Soybean Maturity Groups, Environments, and Their Interaction Define Mega-Environments for Seed Composition in Argentina. Crop Science, 46, 1939-1947. http://dx.doi.org/10.2135/cropsci2005.12-0480

[21] Bellaloui, N., Smith, J.R., Ray, J.D. and Gillen, A.M. (2009) Effect of Maturity on Seed Composition in the Early Soybean Production System as Measured on Near-Isogenic Soybean Lines. Crop Science, 49, 608-620. http://dx.doi.org/10.2135/cropsci2008.04.0192

[22] Bellaloui, N., Mengistu, A., Fisher, D.K. and Abel, C.A. (20112) Soybean Seed Composition Constituents as Affected by Drought and Phomopsisin Phomopsis Susceptible and Resistant Genotypes. Journal of Crop Improvement, 26, 428-453. http://dx.doi.org/10.1080/15427528.2011.651774

[23] Bellaloui, N., Hanks, J.E., Fisher, D.K. and Mengistu, A. (2009) Soybean Seed Composition Is Influenced by Within-Field Variability in Soil Nutrients. Crop Management, 8.

[24] Zu, Y. (2004) Intraspecific Responses in Grain Quality of 10 Wheat Cultivars to Enhanced UV-B Radiation under 
Field Conditions. Journal of Photochemistry and Photobiology, 74, 95-100. http://dx.doi.org/10.1016/j.jphotobiol.2004.01.006

[25] Gao, W., Zheng, Y., Slusser, J.R., Heisler, G.M., Grant, R.H., Xu, J. and He, D. (2004) Effects of Supplementary Ultraviolet-B Irradiance on Maize Yield and Qualities. A Field Experiment. Photochemistry and Photobiology, 80, 127-131. http://dx.doi.org/10.1562/2004-05-03-RA-156.1

[26] Kakani, V.G., Reddy, K.R., Zhao, D. and Sailaja, K. (2003) Field Crop Responses to Ultraviolet-B Radiation: A Review. Agriculture and Forest Meteorology, 120, 191-218. http://dx.doi.org/10.1016/j.agrformet.2003.08.015

[27] Reddy, K.R., Hodges, H.F., Read, J.J., McKinion, J.M., Baker, J.T., Tarpley, L. and Reddy, V.R. (2001) Soil-PlantAtmosphere-Research (SPAR) Facility: A Tool for Plant Research and Modeling. Biotronics, 30, 27-50.

[28] Hewitt, E.J. (1952) Sand and Water Culture Methods Used in the Study of Plant Nutrition. Technical Communication No. 22, Farmham Royal Commonwealth Agriculture Bureaux, Bucks, 187-190.

[29] Wilcox, J.R. and Shibles, R.M. (2001) Interrelationships among Seed Quality Attributes in Soybean. Crop Science, 41, 11-14. http://dx.doi.org/10.2135/cropsci2001.41111x

[30] Boydak, E., Alpaslan, M., Hayta, M., Gercek, S. and Simsek, M. (2002) Seed Composition of Soybeans Grown in the Harran Region of Turkey as Affected by Row Spacing and Irrigation. Journal of Agriculture and Food Chemistry, 50, 4718-4720. http://dx.doi.org/10.1021/jf0255331

[31] Gao, W., Zheng, Y., Slusser, J.R., Heisler, G.M., Grant, R.H., Xu, J. and He, D. (2004) Effects of Supplementary Ultraviolet-B Irradiance on Corn Yield and Qualities: A Field Experiment. Photochemistry and Photobiology, 80, 127131. http://dx.doi.org/10.1562/2004-05-03-RA-156.1

[32] McKenzie, R.L., Aucamp, P.J., Bais, A.F., Björn, L.O. and Ilyas, M. (2007) Changes in Biologically Active Ultraviolet Radiation Reaching the Earth’s Surface. Photochemistry and Photobiology Sciences, 6, 218-231. http://dx.doi.org/10.1039/b700017k

[33] WMO (2006) Scientific Assessment of Ozone Depletion. Global Ozone Research and Monitoring Project-Report No. 50. WMO, Geneva.

[34] Egli, D.B., Ramseur, E.L., Yu, Z.W. and Sullivan, C.H. (1989) Source-Sink Alterations Affect the Number of Cells in Soybean Cotyledons. Crop Science, 29, 732-735. http://dx.doi.org/10.2135/cropsci1989.0011183X002900030039x

[35] Zhao, D., Reddy, K.R., Kakani, V.G., Read, J.J. and Sullivan, J.H. (2003) Growth and Physiological Responses of Cotton (Gossypium hirsutum L.) to Elevated Carbon Dioxide and Ultraviolet-B Radiation under Controlled Environmental Conditions. Plant, Cell \& Environment, 26, 771-782. http://dx.doi.org/10.1046/j.1365-3040.2003.01019.x

[36] Katerova, Z., Ivanov, S., Prinsen, E., Van Onckelen, H., Alexieva, H. and Azmi, A. (2009) Low Doses of Ultraviolet-B or Ultraviolet-C Radiation Affect Phytohormones in Young Pea Plants. Biologia Planturum, 53, 365-368.

[37] Mark, U. and Tevini, M. (1996) Combination Effects of UV-B Radiation and Temperature on Sunflower (Helianthus annuus L., cv. Polstar) and Maize (Zea mays L, cv. Zenit) Seedlings. Journal of Plant Physiology, 148, 49-56. http://dx.doi.org/10.1016/S0176-1617(96)80293-8

[38] Mathew, J.P., Herbert, S.J., Zhang, S.H., Rautenkranz, A.A.F. and Litchfield, G.V. (2000) Differential Response of Soybean Yield Components to the Timing of Light Enrichment. Agronomy Journal, 92, 1156-1161. http://dx.doi.org/10.2134/agronj2000.9261156x

[39] Herbert, S.J. and Litchfield, G.V. (1982) Partitioning Soybean Yield Components. Crop Science, 22, 1074-1079. http://dx.doi.org/10.2135/cropsci1982.0011183X002200050044x

[40] Board, J.E., Kamal, M. and Harville, B.G. (1992) Temporal Importance of Greater Light Interception to Increased Yield in Narrow-Row Soybean. Agronomy Journal, 84, 575-579. http://dx.doi.org/10.2134/agronj1992.00021962008400040006x

[41] Schrope, M. (2000) Successes in Fight to Save Ozone Layer Could Close Holes by 2050. Nature, 408, 627. http://dx.doi.org/10.1038/35047229

[42] Qiang, W.Y., Yang, H., Chen, T., An, L.Z. and Wang, X.L. (2004) Effect of the Combination of Cadmium and UV-B Radiation on Soybean Growth. Chinese Journal of Applied Ecology, 15, 697-700.

[43] Mazza, A.C., Boccalandro, H.E., Giordano, C.V., Battista, D., Scopel, A.L. and Ballare, C.L. (2000) Functional Significance and Induction by Solar Radiation of Ultraviolet-Absorbing Sunscreens in Field-Grown Soybean Crops. Plant Physiology, 122, 117-126. http://dx.doi.org/10.1104/pp.122.1.117

[44] Ros, J. and Tevini, M. (1995) UV-B Radiation and IAA Interaction during Growth of Seedlings and Hypocotyl Segments of Sunflower. Journal of Plant Physiology, 146, 295-305. http://dx.doi.org/10.1016/S0176-1617(11)82057-2

[45] Caldwell, M.M., Flint, S.D. and Searles, P.S. (1994) Spectral Balance and UV-B Sensitivity of Soybean: A Field Experiment. Plant, Cell \& Environment, 17, 267-276. http://dx.doi.org/10.1111/j.1365-3040.1994.tb00292.X

[46] Murali, N.S. and Teramura, A.H. (1985) Effects of Ultraviolet-B Irradiance on Soybean.VII. Biomass and Concentra- 
tion and Uptake of Nutrients at Varying P Supply. Journal of Plant Nutrition, 8, 177-192. http://dx.doi.org/10.1080/01904168509363333

[47] Ros, J. (1995) Synergistic and Antagonistic Effects of Enhanced UV-B Radiation at Various Nitrogen Levels in Crop Plants. In: Bauer, H. and Nolan, C., Eds., Proceedings of the First European Symposium on the Effects of Environmental UV-B Radiation, European Commission, Luxemburg, 245-252.

[48] Alan, H., Teramura, N. and Sullivan, J.H. (1994) Effects of UV-B Radiation on Photosynthesis and Growth of Terrestrial Plants. Photosynthesis Research, 39, 463-473. http://dx.doi.org/10.1007/BF00014599

[49] Calderini, D.F., Lizana, X.C., Hess, S., Jobet, C.R. and Zuniga, J.A. (2008) Grain Yield and Quality of Wheat under Increased Ultraviolet Radiation (UV-B) at Later Stages of the Crop Cycle. Journal of Agriculture Science, 146, 456367. http://dx.doi.org/10.1017/S0021859607007447

[50] Obendorf, R.L., Horbowicz, M., Dickerman, A.M., Brenac, P. and Smith, M.E. (1998) Soluble Oligosaccharides and Galactosylcyclitols in Maturing Soybean Seeds in Planta and in Vitro. Crop Science, 38, 78-84. http://dx.doi.org/10.2135/cropsci1998.0011183X003800010014x

[51] Gao, W., Zheng, Y.F., Slusser J.R. and Heisler, G.M. (2003) Impact of Enhanced Ultraviolet-B Irradiance on Cotton Growth, Development, Yield, and Qualities under Field Conditions. Agricultural and Forest Meteorology, 120, 241248. http://dx.doi.org/10.1016/j.agrformet.2003.08.019

[52] Rotundo, J.L. (2009) Physiological Bases of Environmental and Genotypic Effects on Soybean Seed Composition. Paper 12113, Graduate Theses and Dissertations, Iowa State University Ames, Ames.

[53] Sherif, M. (2013) Soybean, Nutrition and Health. In: El-Shemy, H., Ed., Soybean-Bio-Active Compounds, InTech, Rijeka, 453-473. http://www.intechopen.com/books/soybean-bio-active-compounds/soybean-nutrition-and-health http://dx.doi.org/10.5772/54545 